\title{
Social Development in Pakistan: An Analytical Study of Shaping Public Policy
}

\author{
Dr Arshad javed Rizvi \\ Associate Professor \\ Sir Syed University of Engineering and Technology, Karachi: Pakistan
}

\begin{abstract}
The objectives of this research report is to highlight the implication in the social development of Pakistan the conditions and level of progress of social institutions in the present system in sufficient budgetary financial resources and its misuse and wrong allocation deprive the masses from their basic human rights granted under the constitution of Pakistan. Education is the key element of social progress besides many educations policies projects and five to six five years plans has been implemented but couldn't bring positive results due to inefficient political reasons or corruption.
\end{abstract}

Keywords: budgetary financial resources, social development, community-based project

\section{Introduction}

The term "Social Development" is a compound word social and development. The term "social" is mostly used by sociologist and social scientists relate to human interactions for example large group of people and associations that include family neighborhood, associations, communities, societies and formal organizations, these kind of interactions promote culture, values, social networks and institutions, because it has direct connection with welfare means peoples well being means to improve social conditions for this reason the term social development is used.

The second word "development" refers to bring change, progress, growth, evolution in the social set up, it's progress. The term development after the $2^{\text {nd }}$ world war linked with economic modernization in the developing countries. Involving growth and industrialization. Now it is used in a broader sense for political, environmental social, cultural, Gender and economic growth scholars used this term in different ways. In "Sociology" this term refers to social work and social policy. "Sociology" this term refers to social work and social policy. Sociologist has used this term "guided" social change to improve society based projects; psychologists refer this term to child development. It has also been used in "Social Policy" refers to social improvements by government to form "Welfare State" Social policy writers also used the term "Welfare developmentalism".

Social development is used to mean different things e.g. associated with community-based projects in the developing counties like micro enterprises, Co-operating women's group, maternal and child welfare programs procession of safe drinking water, Schools \& Clinics it also comes under government policies concerning social aspect of development such as reducing poverty, reducing literacy, access to health \& education.

Western counties have also payed attention to social development and its interventions such as micro enterprises and conditional each transfer has been replicated in western countries and regarded as "Third Worldist" approach now being used in different parts of the world.

In the late $19^{\text {th }}$ country sociologist first time used this term refers to the process by which societies evolve from traditional and primitive state to have a modern, advanced level of civilization, approach was inspired by Darwin's work. Sociologists Spencer's and summer and anthropologists 'Morgan' and 'Taylor' believed that similar process of evolution govern social evolution or social development. Hobbhous an evolutionary sociologist wrote a book "Social Development" in 1924, challenged the social Darwinist he suggested the adoption of social reforms, he also rejected the Marx and Angels that revolution driven by historical forces. Together with new liberals in Britain, he helped in bringing social legislation and social reforms introduced by the British government in early $20^{\text {th }}$ country. In United States these ideas were promoted by reformers "Progressives".

"A process of planned social change designed to promote the well-being of the population as a whole within the context of a dynamic multifaceted development process." By James Midgley.

The concept of social development makes the nation of "process" social change is "progressive" in nature "transformation" emphasizing the way it challenges existing social condition forms a part of a larger "multifaceted " process comprise of social, political, cultural, environmental, Gender and economic dimensions, "interventionist" requires human agency in the form of programmes, projects, plans, policies to achieve social development goals, it is "productionsist" practice function as investment to bring economic development or social development, it is "universalistic" in scope have concerned with the whole population rather than vulnerable, impoverished and needy groups of people. 


\section{Statements of Problems}

Pakistan never had a long term coherent social development policies for the masses. Due to group of cities and feudal have been the rulers. They did not want masses to be provided full opportunities in all the section of human developments after the completion of 67 years Pakistan is still considered to under develop socially, economically, financially and educationally.

Nearly half of the population suffers from human deprivations even basic social services like education, healthcare, safe drinking water are not access able. There has been a big gap between rich and poor. Economic growth cannot be achieved without the human productivity. They cannot be considered mere as a resource for economic development.

So concern should be building human capabilities in the social development sectors to bring growth and employment opportunities because the social problems are deep rooted in the prevailed social, political, economical, and in the institution system of Pakistan, so weak insufficient system of policy implementation cannot be workable until policies are viable so my Hypothesis is:

"In efficient policy implementation cannot be bring over all social development in the country"

\section{Methodology}

This research will mainly be based on qualitative method. For this purpose, different methods will be adopted. Descriptive methods will be used to describe characteristics of Pakistani population, its social cultural conditions to analyze the existing situation. This study will be based upon interviews, surveys interrogation; secondly through exploratory method effort will be made to understand the causes of the situation. Third, the approach will be explanatory method to explain and analyze the research problem.

\section{Challenges to Social Development and Policy Making in Pakistan Poverty}

Most president widespread problem of Pakistan is poverty. Two third of Pakistan's population lines below the poverty line means they are unable to purchase their basic needs showing serious human deprivations two third of adult population are unable to read or write, half of the population cannot get access to basic social service like health care and safe drinking water, GDP growth rate is low and income per capita is very low.

All the governments in Pakistan has been placing more emphasis on high economic growth it has never been their strategy to fulfill the basic need of the poor population only little attention is paid to provide the social service of education health, safe water and low income housing.

Subsides in budget for rich in the form of lane concessions and fiscal incentive are fifteen times more than the subsides for poor's only $0.3 \%$ of GNP transfer to poorest in the form of Zakat and bait-ul-maal.

Currently Pakistan is preparing a Poverty Reduction Strategy Paper (PRSP) that proposes to link poverty alleviation to the provision of education, health, nutrition and empowerment of women as well as to ownership of assets in rural areas. Additional financial resources are being earmarked and the implementation mechanism for the poverty alleviation programme is also being put in place. The Government's economic revival plan includes a programme of special schemes of small public works in most poor urban and rural areas, a programme of food supplement scheme and the establishment of a micro-credit bank. In the past, many such schemes were developed, but due to lack of institutional mechanisms to implement and monitor the programme, the number of people in poverty kept on increasing.

\section{Challenges to Education}

Pakistan had been lacking of long term policy for educating it's masses. The Pre dominant feudal cultures in Pakistan don't want poor's to be educated so never give priority to education during the first. School children educational challenges facing Pakistan are huge illiterate population is half of adults primary school enrolment is $82 ? \%$, 55\% are dropouts in the primary education only $20 \%$ enrolled in the secondary education, $3 \%$ for technical and vocational training that improve the productive capacity of individual. They are 4 times more productive compare to working in agriculture sector.

Some steps have been taken by the government to promote education and girls education is given emphasis. "Social action plan" which is feuded by external doners have objections of access to quality education, health \& safe drinking water in the rural area. To promote no formal education the prime minister's literacy commission was setup. For the support of private sector and local Communities National Education Foundation was setup to provide educational facilities for the under privileged yet to quality teacher's training are the persistent problem.

\section{State of Employment in Pakistan}

Despite high rate of population growth and increased economic activity, the number of people employed between 1993 and 1999 has not gone up accordingly. In 1993, 32.45 million people were employed, which went 
up to only to 38.59 million by 1999 . Most of the employment took place in the rural areas.

Our country in agrarian about half of labour fore engaged in agriculture and in manufacturing, mining and trade only quarter of the labour force is engaged. Labour force in Punjab is $65 \%$ in sindh is $21 \%$ and of the total $13 \%$ are women in 1993 The rate of unemployment has increased about 5\%and over 6\% within 1999 compare to rural rate of unemployment is loser then urban.

\section{Financing \& Social Development in Pakistan}

Being a developing country spents small amount of on social sector protégé, for the last 15 years government has been spending only $2 \%$ of GNP where as in other countries it percentage is 4 to $5 \%$ whenever there unconstraint on financial resources, educational expenditure comes under pressure poor implementation of social policies want the financial and material resources. The 1999-2000 Budget allocated Rs.7.3 billion to education out of a total budget of Rs642 billion. The expenditure on education increased from Rs.0.9 billion in 1998-99 to Rs.1.6 billion. The then government also proposed to increase the GNP share of education from the current 2.7 percent to 4 percent by the year 2002 .

In the allocation of resources constrainment of provided budget makers is obvious specially in the social development sector because they have to rely for the release of money from the federal sector, remain uncertain and in adequate.

\section{Latest reports by Social Policy and Development Centre (SPDC)}

The social policy and development centre (SPDC) is non-profit research think tank, has made significant contribution in the field of social development about issues of pro-poor growth and on the Pakistan's policy making agenda for social development.

1) Gender and social vulnerability to climate in Sindh.

This report consolidates the findings of the research project entitled 'Gender and Social Vulnerability of Climate Change: A Study of Disaster Prone Areas in Sindh'. The project is part of Climate Change Adaptation, Water and Food Security in Pakistan -- a research initiative of the International Development Research Centre (IDRC), Canada. The study investigates the gender dimensions of socio-economic vulnerability to climate change among rural communities of disaster prone areas in four districts of Sindh -- Badin, Dadu, Thatta and Tharparkar. In addition to this consolidated report, working papers on each study district are also being published, which provide detailed analyses of social vulnerability in the local and national context.

2) Growth and income inequality on poverty. The case of Pakistan (1988-2011)

This report assesses the distributional characteristics of growth in Pakistan by applying statistical techniques suggested in the empirical literature on poverty and income inequality. An attempt is also made to determine the relative contribution of economic growth and distribution of income to changes in poverty.

Various episodes of growth are considered during the period 1988-2011. The findings of the research will facilitate policy makers to evaluate growth strategies in terms of pro-poorness or growth with equity.

3) Determinants of child schooling, work and idleness: The case of Punjab province.

This paper analyses the determinants of child activity with regard to schooling, working or neither schooling nor working in the age cohort 5-14 years. Primary data of the Punjab Multiple Indicator Cluster Survey (MICS) conducted in 2010-11 has been used for this study. The objective of the study is to assess the relative influence of poverty, gender equity in educational attainment, parental education and mother's autonomy within the household in the decision regarding child activity. Besides presenting a descriptive relationship between child activities and these determinants, multinomial legit is also estimated in the framework of joint probability distributions. In particular, household multidimensional poverty and gender equity in educational attainment have been estimated for this research.

The study finds the positive (negative) and significantly large impact of poverty on the decision regarding child idleness (schooling). In contrast, coefficients associated with educational gender equity, parental education and mother's empowerment have statistically significant inverse (direct) relationship with the household decision of child idleness (schooling). In terms of relative importance as measured by the marginal impact of these variables on the decision not to send children to school or work, multidimensional household poverty outclasses other determinants.

4) Intergovernmental fiscal transfers are an integral part of the federal system of government. In Pakistan, these transfers are routed through the National Finance Commission (NFC) Awards which are of great importance for both the federal and provincial governments. The NFC Award suggests the method for the allocation of transfers through a formula-based revenue sharing mechanism. According to Article 160 of the Constitution of Pakistan, the National Finance Commission has to be constituted every five years by the President of Pakistan. The 7th NFC Award will complete its tenure in June 2015; therefore, it is a constitutional obligation to initiate deliberations on the 8th NFC Award during this fiscal year and announce it before June 2015.

This report analyses the financial implications of the 7th NFC Award on both provincial and federal 
governments and the emerging issues related to the 8th NFC Award such as the impact of the 18th Constitutional Amendment, the IMF programme and the like.

\section{Policy Implications}

The pervasive economic and social development crisis that Pakistan is going through today cannot be resolved by quick-fix technocratic solutions. As the problems are rooted in the prevailing social, economic, political and institutional systems in the country.

To earmark sufficient resources to achieve the social development goals in Pakistan within a realistic and manageable timeframe. It has been estimated that to achieve the targets of education, health, water, nutrition and family planning services, 8 Pakistan will need to spend an additional 2 percent of GNP during the next five years

We need to mobilize the entire civil society to achieve social development goals, not just the government. The experience of other countries shows that NGOs and grassroots efforts have played a major role in spreading primary education, basic healthcare and family planning services, and at a fraction of the costs of the government sector.

No social or economic development goals in Pakistan will be achieved without improving the status of women. n. Human rights of women are violated everyday under the garb of religion, custom and tradition. In every indicator of human development - education, health, employment, and wage rate - females are far behind males,

Finally, there must be commitment at the highest level of decision-making to improve the human condition of Pakistan. This is vital to make a significant difference. It is easy to prescribe institutional changes that are necessary to advance development. But the reforms which are absolutely necessary are the ones the ruling groups have resisted for the last 52 years, for example land reforms, meaningful agricultural income tax, an honest tax collection system, credit to the poor and devolution of power and decision-making to the lower tiers of people's representatives. The current Government has shown that it has the commitment and courage to make hard choices. It is in that context of making hard choices that I take the liberty of suggesting some additional policy measures that are essential in order to make Pakistan a stable country - a precondition for both economic growth and social development. It is absolutely vital for Pakistan to concretely work toward building peace with India. Some of the building blocks for this would be increased trade and other economic cooperation between the two countries; enhanced people-to-people contact and cooperation among civil society organizations. The ongoing efforts include the last two building blocks.

\section{Analysis}

Pakistan has been going through pervasive economics and social development entries quick fix technocratic solution cannot resolve the problem only systematic reformation all the fields of social sectors should be implemented by the government. As the problems are dup rooted cannot be resolved in the prevailing social system economics, social, political and institutional systems need urgent progressive social development reforms. Reforms in the agriculture sector entail importance because our $70 \%$ of the population is engaged with agriculture empowerment of women by eradicating in human practices take vani, women trafficking domestic violence under age marriage can be eliminated for the financial help for the poor there is need of credit institutions. Education is the key factor to empower social development but unfortunately it has elected to the extend there is a need to reform the education policy and its implementation must be ensure to come to the level of global progress. Provision and access of good healthcare, equitable tax system justice for all can only be possible it good governance handle the crisis in the social and economic sector sincerely by eliminating elements of corruption.

\section{Conclusion}

In this era of competitive global markets and national aspiration for a better living standard. This issue of social development has become a political element in national planning. Expanding income and promoting human welfare has no automatic link between, but can be eradicated through deliberate public policy a link between growth and human lives. Public policies focus on public spending on social services, redistribution of income and assists through Fiscal policy, but over the last fifty years subsequent governments could not work on deliberate, future oriented and equitable public policy. This is the main reason that led Pakistan to the current state of both low growth and increased deprivation and poverty.

\section{References}

ADB, 2002. Poverty in Pakistan: Issues, causes and institutional responses. Asian Development Bank. Asian Development Bank Pakistan Resident Mission OPF Building, Shahrah-e-Jamhuriyat G-5/2, Islamabad.

Ahmed, V. and R. Amjad, 1984. The management of Pakistan's economy, 1947-82: Karachi, Pakistan: Oxford 
University Press.

Alesina, A. and R. Perotti, 1999. Budget deficits and budget institutions in fiscal institutions and fiscal performance. J. Poterba and J. von Hagen (eds). Chicago: University of Chicago Press. pp: 13-36.

Alesina, A. and G. Tabellini., 1990. A positive theory of fiscal deficits and government debt. Review of Economic Studies, 57(4): 403-414.

Ansari, J.A., 2001. Macro economic management: An alternative perspective. In fifty years of Pakistan's economy, ed. Shahrukh Rafi Khan, Oxford.

Anwar, T., 2006. Trends in absolute poverty and governance in Pakistan: 1998-99 and 2004-05. The Pakistan Development Review, 45(4): 777-793.

Aziz, S., 2009. Between dreams and realities, some milestones in Pakistan"s history. Karachi: Oxford University Press.

Ansari, J.A., 2001. Macroeconomic management: An alternative perspective. In fifty years of Pakistan"s economy, ed. Shahrukh Rafi Khan, Oxford.

Aziz, S., 2009. Between dreams and realities, some milestones in Pakistan"s history. Karachi: Oxford University Press.

Bengali, K., 2002. Contradictory monetary and fiscal policies. The Daily Dawn, October 10. Karachi, Pakistan.

Bengali, K. and Q.M. Ahmed, 2001. Stabilisation policy vs. growth-oriented policy: Implication for the Pakistan economy. The Pakistan Development Review, 40(4): 453-466.

Burki, S.J., 2007. Changing perceptions, altered reality, Pakistan"s economy under Musharraf, 1999-2006. Karachi: Oxford University.

Cohen, P.S., 2006. The idea of Pakistan. Lahore: Vanguard Books 